\title{
Model Pendampingan Pastoral Bagi Remaja yang Mengalami Broken Home Guna Membangun Citra dan Konsep Diri yang Benar
}

\author{
Wiryohadi ${ }^{1}$, Periskila Sitompul ${ }^{2}$, Gede Widiada ${ }^{3}$ \\ ${ }^{123}$ Sekolah Tinggi Teologi Bethel Indonesia \\ wiryohadi@sttbi.ac.id, periskilasitompul, @ gmail.com, \\ jonathan_gede@yahoo.co.id
}

\begin{abstract}
Abstrak
Masa remaja identik dengan proses pencarian jati diri pribadi dalam kehidupan masyarakat. Proses ini sangat dipengaruhi oleh nilai yang ditanamkan oleh orang tuanya sejak masa kanak-kanak. Namun, bagaimana jika orang tuanya tidak menjalankan fungsi itu dan anak dalam lingkungan keluarga yang broken. Penelitian ini bertujuan untuk mendapatkan potret lengkap akan model konseling pastoral yang tepat bagi remaja yang mengalami keluarga broken home. Peneliti menggunakan pendekatan kualitatif deskriptif untuk memotret fenomena ini di masyarakat dengan wawancara dan observasi sebagai teknik pengumpulan data. Hasil penelitian menunjukkan bahwa citra dan konsep diri remaja yang mengalami keluarga broken home mengarah kepada citra diri yang buruk dan bertentangan dengan Firman Tuhan. Namun, jika dilakukan konseling pastoral dengan melibatkan keluarga, komunitas dan gembala secara intens, maka kecenderungannya mengarah kepada hal yang positif.
\end{abstract}

Kata Kunci: Remaja; Broken Home; Pendampingan Pastoral

\begin{abstract}
Adolescence is identical with the process of searching for personal identity in community life. This process is strongly influenced by the values instilled by his parents since childhood. However, what if the parents do not carry out that function and the child is in a broken family environment. This study aims to obtain a complete portrait of the appropriate model of pastoral counseling for adolescents who experience broken homes. The researcher used a descriptive qualitative approach to photograph this phenomenon in the community with interviews and observations as data collection techniques. The results show that the image and self-concept of adolescents who experience a broken home family leads to a bad self-image and is contrary to God's Word. However, if pastoral counseling is carried out by involving families, communities and pastors intensely, the tendency will lead to positive things.
\end{abstract}

Keywords: Youth; Broken Home; Pastoral Counseling 


\section{PENDAHULUAN}

Unit yang pertama ditemukan oleh anak untuk mendapatkan sepenuhnya kasih sayang, perhatian, cinta, dan pendidikan adalah keluarga (Novalis et al., 2019). Semua ini diajarkan, dirasakan, dan dibiasakan oleh orang tuanya. Karena itu, pertumbuhan buah hati dipengaruhi oleh pola asuh dan pembinaan yang diterapkan dengan konsisten dalam keluarga (Hulukati, 2015). Fakta ini mengafirmasi bagwa cara dan laku hidup orang tua dalam keluarga memberikan pengaruh yang amat besar dalam proses perkembangan anak, baik dalam pertumbuhan fisik, karakter dan kerohaniannya (Johni Hardori, 2008). Luddin menegaskan bahwa dalam keluarga inilah anak dengan bebas mengekspresikan dirinya dan belajar menjadi pribadi yang memiliki kepekaan sosial yang baik. Unit kecil keluarga ini memberikan bentukan persepsi anak dalam memandang diri (citra diri) dan orang-orang yang ada di lingkungan dirinya berada kelak saat bermain dan bersekolah
(Luddin, 2011). Karena itu, dapat

disimpulkan bahwa keluarga merupakan fondasi dari interaksi sosial yang terdiri dari suami istri dan anak anak (R Rustina, 2014).

Beavers menyatakan bahwa definisi yang mesti dilekatkan bagi keluarga adalah kemampuan untuk memberikan makna hidup bagi seluruh anggota keluarga dalam menjalani kehidupan sosialmasyarakat (Scholevar \& Schwoeri, 2003). Pada umumnya, keluarga dibagi menjadi dua dalam kaitannya dengan peran antara anggota keluarga di dalamnya. Pertama, keluarga fungsional, yaitu keluarga yang memiliki komunikasi baik, mampu saling menerima satu dengan yang lain, mudah beradaptasi dengan berbagai karakter yang ada dalam keluarga dan kecakapan dalam bernegosiasi untuk menyelesaikan konflik yang muncul (Sumarno \& Siska, 2009). Sedangkan yang kedua adalah keluarga disfungsional adalah keluarga yang memiliki komunikasi buruk antara seluruh anggotanya, tidak memiliki kecakapan dalam bernegosiasi dan menyelesaikan konflik yang 
muncul. Akibat dari keadaan ini maka terdapat kemarahan, emosional, kepahitan, dan frustasi. Keadaan ini biasa dilabelkan sebagai unit keluarga yang sering mengalami perselisihan, permusuhan, disharmonis, hingga tahap yang paling menyedihkan adalah perpisahan dan perceraian (Scholevar \& Schwoeri, 2003).

Istilah lain yang diberikan untuk rumah tangga yang rusak dan tidak rukun adalah broken home. Dalam masyarakat secara umum, broken home dipahami sebagai sebutan bagi pasangan suami istri yang telah berpisah atau bercerai yang tentunya didahului dengan pertengkaran (Lestari, 2012). Namun definisi itu hanya dalam arti sempit saja. Dalam artian yang lebih luas, broken home dapat dipahami sebagai kondisi tidak adanya kasih sayang dan kepedulian antar sesama keluarga. (Lie et al., 2019).

Jika ditelisik lebih dalam, anak akan menjadi korban utama dari keluarga yang broken home. Tidak jarang kita menemui anak remaja stress dan frustasi sebagai akibat dari keluarga yang broken home (Willis, 2012). Usia remaja adalah proses pertumbuhan (terutama fisik) telah mencapai kematangannya (Ali \& Asrori, 2012). Usia ini menunjukkan suatu masa kehidupan yang menggantung. Bisa dikatakan remaja itu sebagai kanak-kanak, namun terlalu dewasa dari anakanak pada umumnya. Namun belum juga dianggap sebagai orang yang sudah dewasa. Usia seperti ini yang menyebabkan anak remaja disebut sebagai seseorang yang masih labil. Labil karena mereka tidak dapat mementukan arah hidupnya dengan jelas, dan mudah terpengaruh dengan lingkungan tanpa adanya penyaringan yang ketat terlebih dahulu. Keadaan ini tampak nyata di anak remaja broken home (Aziz, 2015).

Kelabilan yang dimiliki oleh remaja secara teori adalah wajar, sebab World Health Organization (WHO) dan para ahli sepakat bahwa usia remaja, yakni 10-18 tahun adalan rentang pertumbuhan pembentukan konsep diri yang terjadi secara alamiah. Pada rentang usia inilah didikan, perhatian, dan penerimaan terhadap tindakan remaja memiliki peran yang besar. Namun, jika dalam usia 
remaja ini orang tua mengabaikan tugas tersebut dan sibuk dengan pertikaian keluarga, maka mentalitas remaja akan mudah putus asa, frustasi, sulit diatur, bahkan pada taraf yang lebih parah akan melakukan tindakan-tindakan kejahatan yang dilarang secara norma sosial dan hukum (Sumarno \& Siska, 2009). Selain masalah mental, remaja yang dibesarkan dalam keluarga broken home juga terlihat secara nyata mengalami gangguan emosi seperti stress, tidak mudah bergaul atau nyaman dengan orang lain, mudah cemas dan depresi apabila mengalami masalah yang kecil. Selain dampak diatas, terdapat juga sederetan dampak lain dalam segala aspek kehidupan anak. Dalam bidang akademik, karena tidak pernah dibanggakan pencapaian hasil studinya, maka motivasi belajar remaja akan menurun yang nantinya berpengaruh kepada hasil belajarnya. Dalam kehidupan sosial, karena tidak dididik bagaimana memiliki kecerdasan emosional dan penyaringan sosial (komunitas yang baik yang dapat dimasuki) di masyarakat, maka ketika bergaul, kecenderungan untuk terpengaruh hal buruk sangat tinggi. Mulai dari merokok, mabuk-mabukan, dan pada taraf yang lebih parah adalah melakukan hubungan free sex. Demikian juga secara fisik, jelas nampak dampaknya dari berat badan yang terus meningkat akibat mudah depresi seperti dinyatakan diatas (Cipta, 2017). Semua dampak ini menyebabkan konsep dan citra diri remaja menjadi rusak.

Fakta diatas telah menjadi wake up call bagi gereja dan institusi rohani untuk melakukan tindakan yang dirasa perlu untuk penanggulangan masalah anak yang mengalami broken home agar kembali memiliki citra dan konsep diri yang Alkitabiah, yaitu lonsep yang memandang diri berharga sesuai gambar dan rupa Kristus (Pantan, 2016). Ini adalah tugas gereja sebagai tubuh Kritus yang melaksanakan tanggung jawab pastoralia bagi jemaat. Karena itu, langkah-langkah praktis dan implementatis mesti diambil oleh gereja supaya generasi muda yang terdapat dalam naungan gereja dapat terselamatkan. 
Gereja bisa saja melakukan konseling kepada anak secara langsung untuk merubah paradigma dan sikap dia terhadap keluarganya yang broken home. Tetapi, melihat lingkup atau unit yang lebih intens bertemu adalah keluarga inti dari sang anak yang mengalami broken home itu. Maka, perlu dirangkul pihak lain yang dapat membantu pelaksanaan pendampingan pastoral terhadap keluarganya, yaitu orang tua yang bersangkutan (Muryati, 2018b).

Pendampingan pastoral di Indonesia secara umum dikembangkan oleh Van Beek pada tahun 1982 yang bekerja sama dengan Wiryasaputra. Mereka mulai mengembangkan konsep konseling pastoral secara khusus dalam konteks Indonesia dengan melakukan penelitian sederhana akan konsep-konsep dan model yang tepat sesuai kategori. Selanjutnya, mereka melakukan penerbitan dan pelatihan pendampingan psikologis. Usaha mereka ternyata tidaklah siasia karena hasil dari eksperimen dan penelitian mereka tersebar ke seluruh Indonesia. Selanjutnya, karena kebutuhan konkret dalam masyarakat yang muncul akibat persoalan manusia dalam aspek emosional, mental, sosial dan spiritual, dikembangkan lagi model pendampingan pastoral. Pengembangan ini menimbulkan persoalan yang bukan hanya semakin beragam, melainkan juga semakin kompleks (Sumarno, 2008).

Melalui paparan di atas, dengan sederhana dapat didefinisikan bahwa pendampingan pastoral adalah wadah pelayanan yang dikerjakan oleh gereja (dalam artian organisasi maupun organisme) guna memberikan pertolongan, bantuan, bahkan penyembuhan bagi masyarakat gereja dalam menghadapi dan mencari solusi masalah kehidupan mereka (Engel, 2020). Karena itu pendampingan pastoral adalah usaha yang harus disengaja untuk dilakukan agar dapat memberikan pertolongan kepada orang atau kelompok yang sedang menghadapi masa sulit, supaya masalah tersebut tidak menjadi gangguan dalam perjalanan hidupnya (Christi, 2012).

Pihak yang bertanggung jawab adalah pendeta, gembala, pelayan gereja, guru sekolah 
minggu, dan jemaat yang terpanggil menjadi konselor.

Wiryasaputra dan Handayani memberikan ciri khas yang membedakan pendampingan konseling umum dengan konseling pastoral. Menurut mereka, pendampingan pastoral komunitas Kristian membangun prinsip dan solusi pemecahan masalahnya berlandaskan perspektif inkarnasi Tuhan Allah dalam pribadi dan karya Yesus Kristus. Landasan ini karena dalam fakta inkarnasi yang Allah lakukan dalam diri Yesus Kristus, terdapat karakter-karakter Allah akan umat manusia. Di dalamnya terdapat sikap yang mengasihi seluruh umat manusia. Selain itu, terdapat pula prinsip menertibkan, menciptakan, menghidupkan, menyelamatkan, memperdulikan, memperhatikan, merawat, mendampingi, mengubah, menumbuhkan, mengampuni, dan sebagainya (Wiryasaputra \& Handayani, 2013). Hal ini menjadi urgensi penting karena adanya the lost of Pastoral Ministry di gereja masa kini (Johni Hardori, 2014).

Pembuatan dan penerapan model konseling kepada remaja yang mengalami broken home menjadi urgent melihat banyaknya anak remaja masa kini yang mengalami itu (Nadya Paramitha et al., 2019), dan peranan dari konseling pastoral yang signifikan dalam menanggulangi masalah itu. Setidaknya terdapat tujuh tujuan dari konseling pastoral yang dapat melahirkan model spesifik dalam menghadapi remaja yang mengalami broken home. Ketujuh tujuan itu adalah berubah menuju pertumbuhan, mencapai pemahaman diri secara penuh dan utuh, belajar berkomunikasi yang lebih sehat (Novalis et al., 2019), berlatih tingkah laku baru yang lebih sehat, belajar mengungkapkan diri secara penuh dan utuh, dapat bertahan, menghilangkan gejala-gejala yang disfungsional dan membantu orang yang didampingi untuk menghilangkan atau menyembuhkan gejala yang mengganggu sebagai akibat dari krisis (Nugroho, 2017).

Penelitian ini bertujuan memberikan model konseling pastoral bagi remaja yang 
mengalami atau ada di lingkungan keluarga broken home. Penelitian terkait pernah dilakukan oleh (Aziz, 2015) dan (Nadya Paramitha et al., 2019) yang menyoroti secara menyeluruh perilaku sosial anak yang mengalami keluarga broken home. Lain halnya dengan (Agustina, 2016) yang menyoroti aspek komunikasi Self Disclosure dalam keluarga broken home. Sementara dalam penelitian ini, peneliti mengembangkan model pendampingan pastoral yang dapat dilakukan oleh pihak gereja dan keluarga.

\section{METODE PENELIAN}

Penelitian ini menggunakan metode kualitatif deskriptif. Penggunaan metode penelitian ini agar peneliti dapat secara alamiah mendapatkan data dari lapangan yang membahas mengenai strategi pendampingan pastoral bagi anak yang mengalami broken home (Chandra, 2019). Konsep pendampingan ini berangkat dari teori-teori yang digunakan dalam memotret keadaan dilapangan.

Peneliti menggunakan teknik triangulasi data untuk mengumpulkan data yang terdapat di lapangan. Penelitian ini dilakukan di Kecamatan Pancur Batu pada bulan Maret hingga September 2020 yang seyogianya hanya sampai bulan Juli. Perpanjangan waktu penelitian dikarenakan peneliti melakukan validasi data kepada para informan setelah melakukan analisi data.

\section{HASIL DAN PEMBAHASAN}

Konsep diri adalah cara pandang seseorang terhadap dirinya sendiri. Hal ini sama dengan citra diri mereka di hadapan mereka. Berpikir mengenai dirinya sendiri merupakan kegiatan yang dilakukan oleh kebanyakan orang. Dibandingkan dengan memikirkan orang lain, manusia tentu lebih mengutamakan dirinya eksis di lingkungan sosial masyarakat. Banyak faktor yang menjadi citra diri seseorang. Pertama-tama adalah faktor genetik memainkan peranan yang sangat besar. Faktor genetik yang penulis maksud adalah kehidupan sosial dari orang tua mereka. Baik dalam berinteraksi dengan keluarga, kerabat, teman dan interaksi orang lain. Selain faktor 
genetik, konsep diri dipengaruhi akan peristiwa-peristiwa masa lalu manusia. Apabila mereka sering mengalami peristiwa yang pahit, maka citra diri mereka akan pahit. Hal ini terbukti dari tokoh Alkitab bernama Naomi yang dalam hidupnya banyak mengalami hal-hal yang menyakitkan sehingga dia tidak mau dipanggil lagi Naomi, yang artinya diberkati, berbahagia, atau manis. Melainkan dipanggil Mara, yang artinya pahit (bitter) (Muryati, 2018a).

Pengamatan terhadap diri yang terus dilakukan oleh seseorang sampai kepada taraf mengkristal akan menjadi sifat atau karakter yang dirinya pandang tentang dirinya sendiri. Inilah yang disebut dengan konsep diri. Brooks mendefinisikan konsep diri sebagai persepsi fisik, sosial, dan psikologis tentang diri kita sendiri yang kita peroleh dari pengalaman dan interaksi kita dengan orang lain (Ritonga, 2019).

Bierhoff menegaskan bahwa konsep diri terbentuk juga dari hubungan antara sesama manusia. Menurutnya, konsep ini bagaikan bayangan cermin, ditentukan sebagian besar oleh peran dan hubungan orang lain, apa yang kiranya reaksi orang terhadapnya. Konsep diri ideal ialah gambaran mengenai penampilan dan kepribadian yang didambakannya (Bierhoff, 2011). Bierhoff mengarahkan konsep diri seseorang kepada kesadaran batin yang tetap dalam jangka waktu yang panjang, lalu pengalaman yang berhubungan dengan "aku" dan membedakan "aku” dari yang bukan "aku”. Kita mencintai diri kita bila kita telah dicintai orang lain dan kita percaya diri kita telah dipercaya orang lain (Marbun \& Nasution, 2021). Dengan demikian konsep diri merupakan suatu pandangan dan perasaan tentang diri. Persepsi tentang diri dapat bersifat psikologi, sosial dan fisik.

Menelisik kepada bagaimana konsep diri remaja korban broken home, Hasil penelitian menunjukkan bahwa remaja korban broken home cenderung menunjukkan dan memiliki konsep diri yang negatif (Pratiwi \& Handayani, 2020). Hal ini tampak jelas ketika peneliti melakukan pengamatan pada pra penelitian 


\begin{tabular}{lll}
\hline sampai & melakukan penelitian & mereka. Berikut ini beberapa model \\
kepada remaja korban broken & pendampingan pastoral yang peneliti \\
home. Konsep diri yang negatif & tawarkan untuk dapat digunakan \\
yang dimaksudkan oleh peneliti & secara umum:
\end{tabular}
berkaitan dengan remaja broken home, antara lain: (i) Cenderung bersikap introvert. Ciri sosial dari anak remaja yang mengalami keluarga broken home terlihat dari kehidupan yang senang hidup dalam kesendirian, tertutup, tidak mudah percaya kepada orang lain, susah bergaul, cenderung menjadi seseorang yang pendiam; (ii) Minder atau rendah diri. Dampak yang terlihat dari anak remaja yang mengalami broken home adalah minder, yaitu keadaan yang rendah diri dengan komunitas sekitarnya; dan (iii) Cenderung bersikap destruktif, yaitu sikap masa bodoh, acuh tak acuh, mudah kecewa, sakit hati jika disinggung sedikit saja dan iri hati.

\section{Model pendampingan pastoral} bagi remaja korban broken home

Usia remaja yang labil dan terdapat pengalaman negatif dalam keluarga saat masa pertumbuhan remaja broken home menyebabkan perlu melakukan pendampingan pastoral secara khusus kepada

\section{Reinforcement melalui Youth pastor}

Peran kakak rohani sangat signifikan membantu remaja korban broken home untuk menemukan konsep diri yang benar. Tidak bisa dipungkiri bahwa remaja broken home telah kehilangan figur orang tua dalam masa pertumbuhan mereka. Oleh karena itu, kaka rohani dapat menjadi orang tua yang menutupi figur ayah-ibu remaja broken home yang selama ini tidak didapatkan. Tindakan yang dapat dilakukan oleh kakak rohani adalah dengan mengajak remaja korban broken home mengikuti kegiatankegiatan gerejawi, seperti persekutuan doa, ibadah pemuda untuk mendapatkan komunitas yang baik, dan kegiatan diluar gereja yang dapat menjadi wadah berbagi perhatian dan kasih sayang. Pendampingan dari kaka rohani ini secara bertahap remaja broken home merasakan kenyamanan dan menganggapdirinya sebagai bagian dalam komunitas tersebut (Rajagukguk \& Sugiono, 2020). 
Pendidikan dengan mentor akan memberikan keterbukaan dan kehidupan pribadi yang menjadi apa adanya tanpa perlu takut untuk dihakimi (Amos Hosea, 2019)

\section{Internalisasi Kebenaran Alkitab} melalui Pembinaan Iman

Sebagai gereja, dasar penyadaran adalah Firman Tuhan. Dengan dasar Firman Tuhan ini, remaja broken home melandaskan citra dan konsep dirinya sesuai dengan Alkitab. Karena itu, gereja perlu melaksanakan kelas-kelas pemuridan. Tujuan dari kelas ini supaya remaja broken home memahami gambar diri mereka di dalam Tuhan.

\section{Layanan secara tidak langsung} melalui bimbingan kelompok

Aspek sosial remaja yang bermasalah mesti diselesaikan dengan kehidupan sosial yang sehat dan mendukung. Karena itu, gereja mengarahkan untuk membangun kelompok remaja yang usianya sebaya dengan mereka untuk dapat saling membangun. Setidaknya dengan kelompok ini, antara para remaja dapat saling terbuka satu dengan yang lain terkait dengan permasalahan yang mereka alami. Tampak jelas kelompok atau komunitas remaja gereja di dalamnya mereka saling memotivasi dan saling berkompetisi dengan fair untuk sebuah keberhasilan. Secara tidak langsung hal ini mempengaruhi remaja korban broken home memiliki kehidupan yang normal seperti kebanyakan anggota kelompok.

\section{Terapi keluarga}

Peran keluarga sangatlah penting bagi pemulihan konsep diri remaja korban broken home, terapi yang dapat dilakukan keluarga adalah memotivasi dengan mencontohkan tokoh tokoh Alkitab, yang walau dibesarkan dalam keluarga tidak lengkap Ayah atau ibu tetapi anaknya bisa berhasil dalam hidupnya.

\section{Dampak pendampingan pastoral} bagi remaja korban broken home

Pendampingan Pastoral hendaknya tidak hanya dilakukan oleh Gembala, tetapi siapa saja yang terpanggil untuk melakukannya. Secara jabatan memang bukan gembala tetapi lebih kepada fungsi penggembalaan. Hal ini akan secara 
DIEGESIS: Jurnal Teologi

Volume 6 No. 2, Agustus 2021.

signifikan membantu remaja membangun konsep diri yang benar.

Berikut dampak dari konseling pastoral bagi anak yang broken home:

\section{Merasa diri berharga}

Ketika gereja melakukan fungsi pendampingan pastoral, maka peneliti menemukan hal yang positif dari remaja korban broken home. Mereka merasa berharga, dalam hal ini mereka sudah mulai menerima keberadaanya.

\section{Percaya diri}

Rasa percaya diri mulai muncul dari diri remaja korban broken home. sebelum mereka belum mendapat pendampingan pastoral ada perasaan kurang percaya diri dan cenderung minder, berkat pembinaan dan pendampingan yang dilakukan oleh gereja mereka sudah bersosialisasi dan tidak menutup diri.

\section{Melibatkan diri kepada pelayanan}

Sebagian dari remaja korban broken home, menunjukkan perkembangan positif, tidak hanya mereka sudah mulai berinteraksi dengan dunia luar, atau terbangun percaya dirinya, ada yang sudah mengabdikan hidupnya untuk melayani Tuhan. Dalam hal ini remaja korban broken home, sudah bisa menerima keberadaannya dan sudah mengerti akan masa depannya dan untuk apa dia hidup.

\section{Memiliki keinginan untuk berhasil}

Pendampingan pastoral yang

intens dari gereja membuat remaja korban broken home, memiliki kerinduan untuk meraih prestasi dan keberhasilan layaknya remaja normal.

\section{Pembahasan Hasil Penelitian}

$$
\text { Remaja broken home }
$$

memiliki kehidupan sosial yang berbeda dengan teman sebayanya yang dibesarkan dalam keluarga yang harmonis. Masa remaja pada dasarnya adalah ajang untuk mencari teman sebanyakbanyaknya. Tetapi tidak demikian dengan remaja broken home. Mereka sulit untuk terbuka dengan teman-teman di sekitarnya dan lebih suka untuk menutup diri dari kehidupan sosial bersama-sama dengan temannya. Permasalahan kehidupan sosial remaja broken home ini karena mengacu kepada tiga aspek cara mereka berlaku. Pertama, cara ia memilih teman. Kedua, bagaimana ia memandang hubungan pertemanan itu. Ketiga, apa yang ia lakukan dalam 
hubungan tersebut. Ketiga hal ini menjadi peluang dari pendampingan pastoral untuk dapat memulihkan keadaan remaja broken home. Permasalahan sosial diatas ternyata dengan mudah diatasi apabila konseling pastoral mewadahi tempat yang tepat untuk mereka bercerita dan menaruh kepercayaan kepada orang lain.

Aspek kedua yang juga berpengaruh adalah mentalitas anak. Mentalitas anak tidak bertumbuh sebagaimana mestinya karena pengalaman masa lalu yang tidak baik. terdapat lubang kosong penyaluran emosinya ketika masa pertumbuhan. Keterpisahan dengan orang tua melahirkan perasaan negatif, seperti kekecewaan, kebencian, dan kemarahan yang dipendam oleh mereka. Apabila tidak ada penyaluran emosi tersebut, maka psikis anak akan terganggu yang mengarah kepada ketidakpercayaan diri untuk menunjukkan kapasitas dan potensi yang ada dalam diri mereka. Bukan hanya itu, mereka juga akan sulit menerima keberhasilan dari orang lain karena remaja broken home ingin setiap orang mengalami apa yang mereka alami.

Aspek spiritualitas, yaitu berhubungan dengan tindakan moral di masyarakat juga cenderung rendah. Remaja broken home dengan berani melanggar norma-norma yang berlaku dimasyarakat, seperti merokok, minum minuman keras, narkoba dan juga free sex. Apabila tidak dilakukan pendampingan pastoral, maka sense of religious mereka akan mati dan tumpul rasa yang menyebabkan tidak ada lagi rasa hormat akan Tuhan (Pakpahan \& Taneo, 2020).

Menghadapi masalah sosial, mentalistas, dan moral remaja broken home, maka model pendampingan pastoral yang dapat dikembangkan dan diterapkan secara intens kepada remaja broken home sebagai berikut:

Pertama, melakukan layanan konseling pastoral secara individu. Pendampingan pastoral individu memudahkan remaja broken home untuk menceritakan secara leluasa persoalan yang dialami. Pendekatan dimulai pada konseling pribadi ini. Karena itu, konselor harus memberikan suasana yang 
tenang, santai, dan rilex saat pelaksanaan konseling. Konseling individu juga menghindarkan remaja broken home dari ketakutan karena "aib" keluarganya dibongkar kepada orang lain.

Kedua, melakukan layanan bimbingan secara kelompok. Tujuan dari bimbingan secara kelompok ini adalah untuk mengajarkan kepada remaja broken home untuk memiliki prinsip hidup berbagi dengan orang lain. Hal ini dilakukan untuk dapat memulihkan aspek sosial mereka di masyarakat ramai. Tentu konseling kelompok yang dimaksud bukanlah konseling kelompok yang anggotanya semua adalah remaja broken home. Kelompok yang dimaksud adalah kumpulan remaja yang berasal dari latar belakang bermacam-macam dengan persoalan pribadi masingmasing. Karena itu, anggota kelompok yang lain harus bisa menerima dan memahami keadaan dari remaja broken home, serta membantu mereka menemukan jati dirinya. Remaja tersebut akan melatih dirinya sambil terus belajar menyembuhkan kekecewaan yang ada di hatinya (Christi, 2012).

Ketiga, terapi kelompok yang mengalami broken home.

Penerapan strategi ini ditujukan kepada para remaja yang juga sama mengalami broken home. Peranan orang-orang yang mengalami masalah yang sama akan memberi semangat untuk yang lain.

\section{SIMPULAN DAN \\ REKOMENDASI}

Remaja broken home

tumbuh dalam ketidakwajaran karena dalam usia pencarian identitas, mereka tidak mendapatkan asupan kasih sayang yang utuh dari orang tuanya. Menghadapi masalah ini, gereja sebagai unit rohani yang Tuhan percayakan untuk menggembalakan domba memiliki tugas untuk memulihkan mentalitas, psikologi, dan dampak yang lain yang dialami oleh anak. Karena itu penting dikembangkan metode pendampingan reinforcement yang diterapkan oleh para pemimpin rohani, khususnya youth pastor karena akan lebih mudah terbuka apabila yang melakukan konseling pastoral usianya tidak terlampau jauh. Selanjutnya, internalisasi pemahaman akan gambar dan rupa 
Allah melalui pembinaan iman dalam kelas-kelas pemuridan. Dalam kehidupan sosial, maka gereja harus sengaja melakukan layanan pemulihan remaja yang mengalami broken home secara tidak langsung melalui bimbingan komunitas dalam gereja, yaitu ibadah homogen secara bersamasama dan percakapan-percakapan dalam grup WA, Chat pribadi, dan percakapan lainnya yang diarahkan kepada pemulihan mentalitas remaja. Dengan membangun suasana sosial yang relevan dengan remaja, maka secara bertahap aspek fisik, psikologis, mental, dan sosial remaja broken home dapat dipulihkan.

\section{DAFTAR PUSTAKA}

Agustina, Y. (2016). Self Disclosure Mengenai Latar Belakang Keluarga yang Broken Home kepada Pasangannya. EKomunikasi, 4(1), 1-12. https://www.neliti.com/id/publi cations/78311/self-disclosuremengenai-latar-belakangkeluarga-yang-broken-homekepada-pasanga
Ali, M., \& Asrori, M. (2012). Psikologi Remaja: Perkembangan Peserta Didik. PT Bumi Aksara.

Amos Hosea. (2019). Karakteristik Pendidikan Iman dalam Pentakostalisme. Diegesis: Jurnal Teologi, 4(2), 51-57. https://doi.org/10.46933/dgs.vol 4i251-57

Aziz, M. (2015). PERILAKU SOSIAL ANAK REMAJA KORBAN BROKEN HOME DALAM BERBAGAI PERSPEKTIF (Suatu Penelitian di SMPN 18 Kota Banda Aceh). Jurnal Al-Ijtimaiyyah, 1(1), 3050. https://doi.org/10.22373/alijtimaiyyah.v1i1.252

Bierhoff, M. (2011). Efficiency optimized control of induction machine drives for battery applications. Proceedings - ISIE 2011: 2011 IEEE International Symposium on Industrial Electronics, $\quad$ 585-590. https://doi.org/10.1109/ISIE.201 1.5984223

Chandra, D. C. (2019). FUNGSI TEORI DALAM METODE PENELITIAN KUALITATIF. Reseach Gate. 
Christi, A. M. (2012). Jesus As the Healer. Pemikiran Teolog Gereja Bethel Indonesia Tentang Teologi Pentakosta, 1(1), 249-267.

Cipta, H. (2017). Dampak Perceraian Terhadap Kenakalan Remaja. Edugama: Jurnal Kependidikan Dan Sosial Keagamaan, 3(2), 88-103. https://doi.org/10.32923/eduga ma.v3i2.724

Engel, J. D. (2020). Pendampingan Pastoral Keindonesiaan. Kurios, $6(1)$, 47. https://doi.org/10.30995/kur.v6i 1.153

Hulukati, W. (2015). Peran Lingkungan Keluarga terhadap Perkembangan Anak. Musawa, 7(2), 265-282.

Johni Hardori. (2008). Pola Asuh Orangtua Dalam Memperkenalkan Yesus Kristus Kepada Anak Batita. Edukasi: Jurnal Pendidikan Agama Kristen, 1(1), 65-85.

Johni Hardori. (2014). The Lost of Pastoral Ministry. In Reaffirming our Identity (p. 285). STT Bethel Indonesia.

Lestari, S. (2012). Psikologi Keluarga: Penanaman Nilai dan
Penanganan Konflik dalam

Keluarga. Prenada Media Group.

Lie, F., Ardini, P. P., Utoyo, S., \& Juniarti, Y. (2019). Tumbuh Kembang Anak Broken Home. Jurnal UPMK, 2(3), 114-123.

Luddin, A. B. M. (2011). DasarDasar Konseling: Tinjauan Teori \& Praktik. Cita Pustaka Media Perintis.

Marbun, P. _, \& Nasution, A. F. N. (2021). Improving The Quality Of Information, Communication Technology Based Theology Learning. SISFOTENIKA, 11(1). https://doi.org/10.30700/jst.v11i 1.1057

Muryati. (2018a). Jangan Panggil Aku Naomi. STT Bethel Indonesia.

Muryati. (2018b). Recovering from Grief: Pendampingan Pastoral bagi Penderita Penyakit Terminal. STT Bethel Indonesia. Nadya Paramitha, Nuraeni, N., \& Setiawan, A. (2019). Sikap Remaja Yang Mengalami Broken Home: Studi Kualitatif. Jmcrh, 3(3), 137-149.

Novalis, D., Sumarno, Y., \& Paruntung, J. P. (2019). Penerapan Strategi 
Pembelajaran Kontekstual

Dalam Upaya Meningkatkan

Minat Belajar Pak. Edukasi:

Jurnal Pendidikan Agama

Kristen, 10(1), 27-39.

Nugroho, F. J. (2017). Pendampingan

Pastoral Holistik: Sebuah

Usulan Konseptual Pembinaan

Warga Gereja. Evangelikal:

Jurnal Teologi Injili Dan

Pembinaan Warga Jemaat, 1(2), 139.

https://doi.org/10.46445/ejti.v1i

Pakpahan, G. K. R., \& Taneo, A. Y. (2020). Kajian Sosio - Etis Teologis Terhadap Moralitas Sosial Umat Kristen Di Kecamatan Alak, Kupang Nusa Tenggara Timur. Matheo : Jurnal Teologi/Kependetaan, 10(1), 23-36. https://doi.org/10.47562/matheo .v10i1.99

Pantan, F. (2016). Metafisika Pendidikan Iman di Gereja. Diegesis: Jurnal Teologi, 1(1).

Pratiwi, I. W., \& Handayani, P. A. L. (2020). Konsep Diri Remaja yang Berasal dari Keluarga Broken Home. JP3SDM, 9(1), 17-32.
R Rustina. (2014). Keluarga dalam Kajian Sosiologi. Musawa, 6(2), 287-322.

Rajagukguk, J. S. P., \& Sugiono, L. (2020). Tinjauan Liturgis UnsurUnsur Ibadah Pentakosta Terhadap Kedewasaan Rohani. Matheo : Jurnal Teologi/Kependetaan, 10(1), $37-51$.

https://doi.org/10.47562/matheo .$v 10 i 1.101$

Ritonga, H. (2019). Psikologi Komunikasi. Perdana Mulya Sarana Publishing.

Scholevar, G. P., \& Schwoeri, L. D. (2003). Textbook of Family and Couples Therapy. American Psychiatric Publishin.

Sumarno, Y. (2008). Kecerdasan Emosional dan Kemampuan Berinteraksi Dengan Lingkungan. Edukasi: Jurnal Pendidikan Agama Kristen, l(1), 87-105.

Sumarno, Y., \& Siska, R. (2009).

Kasih Sayang Orangtua Mempengaruhi Pertumbuhan Remaja. Edukasi: Jurnal Pendidikan Agama Kristen, 2(1), 40. 
DIEGESIS: Jurnal Teologi

Volume 6 No. 2, Agustus 2021.

Willis, S. S. (2012). Remaja dan

Permasalahannya. Alfabeta.

Wiryasaputra, T. S., \& Handayani, R.

(2013). Pengantar Kedalam

Konseling Pastoral. Asosiasi

Konselor Pastoral Indonesia. 